\title{
Ideology of Bedhayan Dance in Surakarta in Globalization Era
}

\author{
Sawitri ${ }^{1}$, Bani Sudardi ${ }^{2}$, Wakit Abdullah ${ }^{3}$, I Nyoman Chaya ${ }^{4}$ \\ $\{1$ sawitri univet@g.mail.com\} \\ 1,2,3,4 Sebelas Maret University, Indonesia \\ ${ }^{1}$ Universitas Bangun Nusantara, Indonesia
}

\begin{abstract}
Culture is born from an artist/a choreographer's idea and thought. Bedhayan is a dance performed in group by minimally five dancers and maximally unlimited number of dancers corresponding to the theme and message to be delivered by artist/choreographer, while its makeup and fashion are varying corresponding to the character performed. Data was collected using descriptive qualitative method with interview, book, journal, document, photograph, video, magazine, and etc. Choreographers have ideology in creating their work as the artists' self actualization, existence, economic welfare, innovation and art creativity. Ideology contained in bedhayan is also an answer to art and work that will keep evolving along with the time development. Globalization affects human's mindset. Globalization current cannot be warded off as the development is a flowing process. The change of mindset affects human's work.
\end{abstract}

Keywords: ideology, bedhayan, globalization

\section{Introduction}

Working in the form of idea and putting it onto a work is not easy. The expression of idea and thought is a hard work and needs thinking and working abilities requiring persistence and competency. The existing idea only stopping in the mind will not be manifested into work. Art work constituting the embodiment of idea includes fine art, literary work, craft art, theater art, and dance art. This writing will discuss the ideology of dance departing from an artist's wish to work (background).Background can also be the manifestation of an individual's or a dance artist's work. A good work must pass through a maturely processing of idea. The good expression of idea will result in a good work [1]. It is also called the concept of working. A concept can be created through artist's experience, innovation or novelty, and time condition [2]. This concept adjustment due to some factors aforementioned highly affects the product of work [3] Innovation results from an artist/choreographer's creative process to create a new non-monotonous work thereby can entertain the art enjoyers; in addition this creative process will create more modern new work [4].

Artwork manifested into movement includes dance and theatrical artworks. This article emphasizes on dance work. Dance is a series of daily movements that have been stylized and manifested into dancing movement with a combination of sekaran, floor pattern, fashion, and 
makeup as supporting elements. Dance is also an expression of idea and thought including a series of stories existing taking a little story or even the one created only as an idea resulting from an artist/choreographer's imagination [5]. The wish expressed into works will be varying between one art/choreographer and another. Every human has different background and experience, thereby creating different forms of work [6]. Working should build on strong concept. The production of work must pass through a process including idea and thought maturation corresponding to the standard of artistic work rather than occurs instantaneously, so that beauty is difficult. In bedhayan dance, the movements used are the modern ones. Dancing movement in bedhayan has changed with the addition of volume, floor pattern, and changing make-up and fashion [7].

The dance inspiring the birth of bedhaya dances, particularly bedhayan, is bedhaya ketawang from Surakarta Palace and bedhaya semang from Yogyakarta Palace, both of which have shared ideology as they are related to the King. It is the King having power over leadership, kingdom management, and palace management. All governmental activities are conducted with the King's permission. Kingdom's order and rule are determined based on the King's knowledge. It is in line with Daryanto [8] . Bedhayan dance does not contain order and rule because this dance is indeed out of the court's corridor. Both of them are still interrelated because there are inspiration, creativity, and form from the previous dance. The form of former dance is bedhaya ketawang and the current dance is bedhayan one. Bedhayan dance consists of bedhayan Bengawan, bedhayan Angon - Angin, bedhayan Sarporodra, bedhayan Silikon, and etc.

Each work is born from concept maturation that can be enjoyed better by its enjoyers. The product of dance work is considered as consistent with standard when it is acceptable to society. Work assessment can be dependent on art enjoyers. Enjoyers will make an assessment when they have experience with working; capability of assessing is defined as having competency and understanding on art. There are many types of dance works: military, couple, and group. There are so many forms and varieties of dance as well. One example of in-group dance is bedhaya dance. Bedhaya is a dance work performed by five to nine female dancers wearing same suits with different names, from batak to buncit, with Javanese bride/bridegroom-styled makeup [9]. Bedhaya dance exists in the Court (Palace) indicating that the King has full power. It means the perpetuation of power or in other words, the King has sacred work in the form of bedhaya dance.

Bedhaya dance growing originally in the Court develops beyond the Court in its development, particularly the one other than bedhaya ketawang. The sacred bedhaya isbedhaya ketawang in the court (palace), its ideology is for divine purpose and king's legitimacy, and this dance is performed only once a year for jumenengan event. Meanwhile, the bedhaya developing out of the court is a new form called bedhayan [10]. Development is something inevitable because human mindset will not cease and will keep innovating in working. Time current cannot be warded off because society feels being affected with a development, so that human creativity cannot be inhibited by the pakem of the court's dance. Bedhayan is a dance resulting from human creativity and the freedom of working cannot be inhibited by anyone and any policy so that the work seems to explore the movement in more relaxed way [11]. An innovative and attractive form of work is more desirable. Artists will keep moving, working, and fulfilling the society's desire. Behind a work produced, artists imply an ideology underlying the work produced because they want to express moral message, to raise phenomenon, and even want to realize the soul's desire into real action. Thus, art behavior becomes reasonable self habit, thinking, and action pattern to complement a certain objective with mechanism [12]. Ideology is also a thinking to develop a cultural product by 
exploiting anything to be a product that result in exchange value. Exchange value canbe not only money but also self existence, popularity, position within artist community, fame and even devotee for many works known by the public that in turn will increase the product order to artists/choreographer with respective interests and purposes.

Artists have something to be realized and underlying the creation of work. The work is created as the manifestation of an ideology. It is this artist's ideology that will be revealed in this study. Working has objective and expectation to be realized inside artist/choreographer. There must be several objectives inside artists: inner satisfaction, self-existence, selfactualization, and also economic improvement and welfare [13].

\section{Research Method}

The method used was descriptive qualitative one. Data collection was conducted using interview, library study, and document study. All data collected could be sorted or grouped by adjusting primary and secondary data. Data deriving from reference served as secondary data for interview data. Document study on photograph, video, and manuscript resulted in strong data to reveal an artwork. In-depth interview was conducted to reveal and to understand indepth each artist/choreographer. From the result of interview, it could be seen the ideology contained in a work, because all artists have their own ideology corresponding to their mindset and background.

\section{Results And Discussion}

Artwork is artist and choreographer's creative process. This creative process is expressed in the form of work. In this case, the work constitutes the inspiration of court dance, bedhaya. Artists have their own working creativity. An artwork will be corresponding to the artists' background. It is this experience that makes the work having its characteristics. This background includes content, tradition. Traditional artists can move to contemporary art because they think that working should have typical characteristics in order to be well-known and remembered by art enjoyers. The artwork different from common work will make the enjoyers watching and even studying it curiously.

The result of professional performance can be seen from its creating process. This working process will result in a product and can be enjoyed by art enjoyers. A mature process is a way to make a work successful maximally. Phenomenon should be an idea because this critical, innovative, and artistic work will be enjoyed and remembered by art enjoyers. Art is indeed a real work resulting from idea and thought sometimes coming suddenly from the result of reflection, soul agitation, social condition, personal experience, and friend or colleague's real story, so that the working inspiration can come from anywhere. Artists can work independently to express their idea. The concern with art preservation is an artist's reason of always expressing his/her idea into artwork form.

Dance artists will keep working and creating innovative work in order to make them keeping existent and known. Working needs heart and soul sincerity because it takes time, effort, thought, and willingness. The existence is also a manifestation of working sincerity to preserve culture. Art will be existent because it is brought into reality. In addition, this concern is important to the existence of art. Dance art inspired with bedhaya is the manifestation of 
artists' concern with the existence of bedhaya dance product. Cultural preservation is dance artists' attempt of keeping the dance existent.

The ideology of working can be elaborated as follows:

1. Market ideology: an artist/choreographer produces a work due to market phenomenon, for example contemporary dance work that is liked by art observers and enjoyers. Choreographers put their idea and thought onto work by seeing the market chance so that finally the work will be enjoyed by art observers.

2. Economic ideology: through this ideology, artists/choreographers work to fulfill their need and finally to improve economic condition or to get financial benefit. Welfare will be achieved with good financial condition.

3. Self existence ideology: this ideology positions an artist/a choreographer to keep working. In an innovative work product, creativity is the artists' way of giving others artists and cultural community a space to express their idea. Working actively will keep their name inside cultural lovers, enjoyers, and spectators' heart.

4. Working Freedom ideology. Working in bedhayan dance is no longer afraid of performing wrong movement, pakem, music, and floor pattern. Innovative working in bedhayan form is no longer ritual in nature, so that puasa mutih (mutih fasting), puasa nrowot, and sterility are no longer important. There are no longer sesaji (offering) and magic ritual.

5. Social and Cultural ideology: Social cultural ideology means that through working an artist can socialize with other artists and can cooperate with dancers, attendants, sinden (singers), crews, and art and cultural enjoyer community.

Ideology in globalization era emphasizes on economic improvement, many consumers need an innovative and creative entertainment. It is the entertainment that is not boring and can be enjoyed. Creativity and innovation making the spectators and the art enjoyers impressed so that the spectators watch bedhayan dance joyfully in globalization era. Bedhayan dance in globalization era is innovative, viewed from the following aspects:

1. Movement: The movement in bedhayan dance is not corresponding to pakem just like bedhaya ketawang including Maju Beksan, Beksan, Mundur Beksan, and it is performed not in order, corresponding to choreographers or artists' idea and thought

2. Volume: Movement volume should not be adjusted with the pakem of bedhaya dance.

3. Floor Pattern: Floor pattern and post of bedhaya ketawang have been abandoned, there is no longer jejer wayang montor mabur, and not all posts in bedhaya ketawang should be used in this bedhayan dance. The freedom of expression makes the dance work corresponding to enjoyers/spectators' willingness and it is an innovative entertainment.

4. Accompaniment: The accompaniment used should not be slendro or pelog but only slendro or pelog.

5. Time: Time duration of bedhaya ketawang is 2 hours, but in this bedhayan it can be only 15,25 , or 30 minutes.

6. Makeup: Makeup in bedhaya ketawang is Javanese bride/bridegroom-styled makeup including Dhodhot and paes for bedhayan corresponding to innovation, creativity, and theme to be expressed by the dance artists/choreographers. Makeup can be beautiful, frightening, and combination of the two.

7. Clothes: Javanese bride/bridegroom clothes worn in bedhaya ketawang should not be worn in bedhayan dance. Bedhayan dance uses any kind of clothes including kain jarit and kemben or colorful cloths or combination of the two.

8. Lighting: the lighting existing in bedhaya ketawang can be modified into more modern one in bedhayan dance. Colorful lamps may be more amusing and beautiful. 
Stage layout: bedhaya ketawang is performed in pendhopo but bedhayan dance is performed in performing hall, office yard, pendhopo, on swimming pool, in the park, etc.

\section{Conclusion}

Ideology of bedhayan in globalization era in Surakarta emphasizes more on economic ideology aiming to improve the economic condition and eventually the welfare of artists and likewise to preserve the culture. Cultural preservation conducted by artists is the manifestation of self existence. It is the manifestation of culture in the form of dance that will be preserved when people are concerned with and preserve it. The product of culture in the form of bedhayan dance in globalization era is the manifestation of preservation and self-existence. Ideology related to welfare is contained in dancer, pengrawit, makeup person, fashion stylist, lighting man, stage layout man, and artists/choreographer's improved welfare.

\section{References}

[1] Althuser, L. 1969. For Mark. London: Allen Lane, 1969.

[2] Fiske, F. Understanding Popular Culture. Yogyakarta: Jalasutra, 2011.

[3] Ansyar, M Nurtaim H. Development and Innovation as well as Creatiity. Jakarta: Education and Culture, 1991.

[4] Prabowo, W.S. Retrospection of Contemporary Dance Work in STSI Surakarta (A Little Note). Paper presented in Seminar on Program DUE-Like of Indonesian Art College of Surakarta on September 28, 1999.

[5] Bergerr, A.A. Signs of Contemporary Culture, An Introduction to Semiotics. Yogyakarta: Tiara Wacana, 2005.

[6] Ampin, S. Kebudayaan, Pakem Tari, Kontemporer Auzaqilia blog, http://zagiali. Wordpres.com/2010/12/14. accessed on April 15, 2015, pp. 21 - 23, 1996.

[7] Bergerr, A.A. Signs of Contemporary Culture, An Introduction to Semiotics. Yogyakarta: Tiara Wacana, 2005.

[8] Daryanto, J. Raja, Karawitan , and Traditional Rite of Surakarta Palace, Journal of Dewa Ruci, Art Study and Creation. Vol. 6 No, july. ISSN 1412-4181. pp. 17 - 18, 2010.

[9] Hadiwidjoyo, K. G.P.H. Bedhaya Ketawang Dance, Its relationship to Astronomy and Sacred Dance in Temples. Surakarta: Radya Pustaka, 1971.

[10] Featherstone, M (ed). Global Culture, Nationalism, Globalization and Modernity. Cetakan ke 2. London: Sage Pabulicatio, 1991.

[11] Cleggp, Creativityard Critical Thinking in the Globalised. University Innovation in Education and Teaching Internasional. Vol. 45. No 3. Taylor \&francis, on Line ). pp. 11-13, 2008.

[12] Althuser, L. About Ideology, Structuralist Marxism, Psychoanalysis and Cultural Studies (Translated from Essay on Ideologi). Yogyakarta, 2005.

[13] K. Saddhono, "Cultural and Social Change of Foreign Students in Indonesia: The Influence of Javanese Culture in Teaching Indonesian to Speakers of Other Languages (TISOL)," in IOP Conference Series: Earth and Environmental Science, 2018, vol. 126, no. 1. 